\title{
Anti-Dislipidemia Effectiveness Test of Turmeric Ethanol Extract (Curcuma Longa) in Male Wistar Mice Given Propylthiouracil (PTU)
}

\author{
Ke Huajing ${ }^{1}$, Florenly ${ }^{2}$, Johannes Bastira Ginting ${ }^{3}$, Fioni $^{4}$ \\ ${ }_{1,2,3,4}$ Master of Clinical Medicine, Faculty of Medicine, Universitas Prima Indonesia \\ johannesbastiraginting@unprimdn.ac.id
}

\begin{abstract}
Dyslipidemia is a lipid metabolic disorder that is a risk factor for coronary heart disease (CHD). According to the American Heart Association, data from 2013 to 2016, as many as 92.8 million adults in America have total cholesterol of more than 200 $m g / d L$. Curcumin, the main compound in turmeric, can lower cholesterol levels due to inhibiting the reabsorption of cholesterol derived from the outside (exogenous) and increasing the enzyme HMG-CoA reductase inhibitor so that fat synthesis can run well. The purpose of this study was to find out the effectiveness of mangosteen peel ethanol extract as an anti-dyslipidemia in male Wistar rats given Propylthiouracil (PTU). This study is an experimental study with a Pre-test and Post-test group only control design approach that uses male Wistar rats as test animals and turmeric extract. The study was conducted in March 2021, at the Herbarium Medanese FMIPA USU, the Pharmacognosy Laboratory of the FACULTY of Pharmacy USU, and the Laboratory of Pharmaceutical Pharmacology USU. Descriptive data analysis (Central tendency and Dyspersi) in the form of lipid profiles (LDL, HDL, Total Cholesterol, and Triglycerides), color, texture, weights. Then analyzed with One-Way Anova if the distributed data is normal, if the distributed data is not normal, then the Kruskal-Wallis test is used. The results and conclusions, turmeric ethanol extract (Curcuma Longa) III (151.70 $\pm 0.95 \mathrm{mg} / \mathrm{dl}$ ) can significantly decrease total cholesterol compared to the control group (178.50 \pm $6.05 \mathrm{mg} / \mathrm{dl})$ (P-value < 0.05). Turmeric ethanol extract (Curcuma Longa) III (110.00 \pm (109-112) $\mathrm{mg} / \mathrm{dl})$ may significantly lower triglyceride levels compared to the control group (167.00 (162-179) $\mathrm{mg} / \mathrm{dl}$ ). (Value $P=0.027$ ). Turmeric ethanol extract (Curcuma Longa) III $(68.50 \pm 1.28 \mathrm{mg} / \mathrm{dl})$ significantly lowered LDL levels compared to the control group $(107.20 \pm 3.60 \mathrm{mg} / \mathrm{dl})$. (P-value < 0.05). Turmeric ethanol extract (Curcuma Longa) III, (61.00 (60-62) $\mathrm{mg} / \mathrm{dl})$ may significantly increase HDL levels compared to the control group (28.50 (37-45) $\mathrm{mg} / \mathrm{dl})$. (Value $P=0.027)$. Turmeric ethanol extract (Curcuma Longa) III significantly lowered SGOT (Value = 0.027) and SGPT (Value P $<0.05$ ) compared to the control group.
\end{abstract}

Keywords: curcuma longa; dyslipedemia; propylthiouracil

\section{Introduction}

Dyslipidemia is a lipid metabolism disorder characterized by an increase or decrease in lipid fraction in plasma and is a risk factor for various diseases that are still a major problem in Indonesia such as coronary heart disease (CHD) (Irmadoly et al., 2014). The main lipid fraction abnormalities are the increase in total cholesterol levels, LDL cholesterol (Low Density Lipoprotein), triglycerides, and decreased HDL (High Density Lipoprotein) cholesterol(Dipiro J et al., 2015); (Ardhani et al., 2017). The disease is also one of the risk factors for atherosclerosis that can cause coronary heart disease (CHD) (D'Agostino et al., 2008). 
According to American Heart Association data from 2013 to 2016, 92.8 million people or $38.2 \%$ of adults in the United States have total cholesterol over 200 $\mathrm{mg} / \mathrm{dl}$ (Aparicio et al., 2021). Cardiovascular disease is the most common noncommunicable disease in the world and was the cause of 17.8 million deaths in 2017 (Wulansari, 2020). The number of heart disease sufferers in Indonesia reached 1,017 million people, while stroke sufferers reached 713,783 people in 2018 (Ministry of Health RI, 2018). Based on estimates from the AHA, $42.8 \%$ or 100,100,000 million American adults over the age of 20 have a total cholesterol level of $200 \mathrm{mg} / \mathrm{dL}(5.17 \mathrm{mmol} / \mathrm{L})$ or higher(Dipiro J et al., 2015). According to Jeppsen et al, the higher the triglyceride levels in an individual's blood the higher the risk of developing cardiovascular disease in that individual(Tawfik, 2020).

From various research results, there are approximately 10,000 types of plants that have been utilized by the community for treatment, disease prevention as well as to increase endurance and restore the freshness of the body (Mursito, 2003). Drug use Natural ingredients also tend to be safer than chemical drugs (Hariana, 2007). One of these natural plants is turmeric which contains the main compound curcumin (Ariani, 2017); (Winarto, 2004). Apart from being an antioxidant, curcumin can reduce cholesterol levels due to inhibiting the reabsorption of cholesterol from outside (exogenous) and increasing the enzyme HmgCoA reductase inhibitor so that fat synthesis can run well (Komang and Laksmi, 2014); (Yunarto et al., 2019). The function of curcumin has been proven in a study of dyslipidemic patients in the Sawotratap village area of Sidoarjo Regency who were given turmeric extract for 12 days. Measurement of cholesterol levels was carried out before and after administration of turmeric rhizome extract. Based on the results obtained by using the Paired t-test analysis test, it is stated that there are significant differences in changes in blood lipid levels in research respondents (Gustomi Rima, 2015). The purpose of this study was to determine the effectiveness of the ethanolic extract of turmeric (Curcuma Longa) as an anti-dyslipidemia in male wistar rats given Propylthiouracil (PTU).

\section{Review of Literature}

Turmeric is the species Curcuma domestica Val (Winarto, 2004), is a traditional medicinal plant (jamu) in Indonesia. The main chemical compounds contained in turmeric are curcuminoids or dyes, which are $2.5-6 \%$. Chemical components contained in turmeric rhizome include essential oils, starch, bitter substances, resins, cellulose and some minerals. Turmeric essential oil content is about 3-5\% (Winarto, 2004). Turmeric has pharmacological effects such as blood circulation and vital energy, eliminating blockage of menstrual laxatives, anti-inflammatory (anti-inflammatory), facilitating childbirth, antibacterial, facilitating bile secretion (cholagogum), laxative fart (carminative) and moisturizing (astringent) (El-Sayed et al., 2011): (Manarin et al., 2019);(Rezzani, Franco and Rodella, 2019);(Sabale, Modi and Sabale, 2013). Dyslipidemia is defined as a lipid metabolism disorder characterized by an increase or decrease in the lipid fraction in plasma. There are several ways to screen or evaluate anti-dysipidemic activity, namely in vivo methods and in vitro methods (Jijith and Jayakumari, 2018; Untari and Pramukantoro, 2020). In Vivo methods include: Triton-induced dyslipidemic mouse model, PTU, and High-Fat Diet. In Vitro method with Caco-2 strain cells or measurement of HMG-CoA Reductase enzyme inhibitory activity. 


\section{Research Methods}

This study is an experimental study with a Pre-test and Post-test group only control design approach using male wistar rats as experimental animals, March 2021. The sample size in this study was calculated by the Federer formula:

Description:

$$
(\mathrm{r}-1)(\mathrm{t}-1) 15
$$

r: Number of samples in each treatment group

$\mathrm{t}$ : Number of treatment groups

$$
\begin{gathered}
5(\mathrm{r}-1) 15 \\
\mathrm{r}-115 / 5 \\
\mathrm{r} 3+1 \\
\text { r } 4
\end{gathered}
$$

\begin{tabular}{|c|c|c|c|c|c|}
\hline No & Variable & How to Measure & $\begin{array}{l}\text { Measuring } \\
\text { instrument }\end{array}$ & $\begin{array}{l}\text { Measurement } \\
\text { Results }\end{array}$ & $\begin{array}{l}\text { Measuring } \\
\text { Scale }\end{array}$ \\
\hline 1. & $\begin{array}{l}\text { Dosage of } \\
\text { turmeric } \\
\text { ethanol extract } \\
\text { (Curcuma } \\
\text { Longa) }\end{array}$ & $\begin{array}{l}\text { The weight and } \\
\text { volume of the } \\
\text { extract and the } \\
\text { extract vehicle were } \\
\text { measured using an } \\
\text { analytical balance } \\
\text { and a volumetric } \\
\text { flask. }\end{array}$ & $\begin{array}{l}\text { Analytical } \\
\text { balances and } \\
\text { volumetric } \\
\text { flasks. }\end{array}$ & $\begin{array}{ll}\text { 1. } & \text { Control } \\
\text { 2. } & \text { Standard }\end{array}$ & ordinal \\
\hline 2. & Lipid Profile & $\begin{array}{l}\text { Lipoprotein } \\
\text { analysis that can } \\
\text { measure blood } \\
\text { levels of total } \\
\text { cholesterol, LDL } \\
\text { cholesterol, HDL } \\
\text { cholesterol, and } \\
\text { triglycerides. }\end{array}$ & Spectroscopic & In mg/dl & Ratio \\
\hline 3. & $\begin{array}{l}\text { Total } \\
\text { Cholesterol } \\
\text { Level }\end{array}$ & $\begin{array}{l}\text { The combined } \\
\text { amount of LDL } \\
\text { cholesterol, HDL } \\
\text { cholesterol, and } \\
\text { triglycerides in } \\
\text { every deciliter of } \\
\text { blood }\end{array}$ & Autocheck ® & In mg/dl & Ratio \\
\hline 4. & Weight & $\begin{array}{l}\text { Weighed using a } \\
\text { scale }\end{array}$ & $\begin{array}{l}\text { analytical } \\
\text { balance }\end{array}$ & In grams & Ratio \\
\hline
\end{tabular}

Based on the results of these calculations, it can be concluded that at least 4 male wistar rats (Rattus norvegicus) are needed in each treatment group. Rat body weight in the range of 180-200gram and have an age between 2-4 months.

Table 1. Aspects of Measurement of Research Variables

\subsection{Tool}

Surgical instruments, laboratory glassware, aluminum foil, blender (Miyako), porcelain cup, desiccator, incubator, slide, cover glass, porcelain crucible, drying cabinet, 
microtube, light microscope, analytical balance (Vibra AJ), oral sonde, oven electric (Stork), water bath (Yenaco), tube clamp, test tube rack, rotary evaporator, centrifugator, set of moisture determination apparatus, UV spectrophotometer (Microlet 3000), injection syringe, furnace (Nabertherm), test tube, animal scale ( Presica).

\subsection{Ingredient}

The materials used in this study were turmeric (Curcuma Longa), ethanol, Aquades, Na-CMC (Sodium-Carboxyl methylcellulose), simvastatin, husks, rat food pellets, phytochemical screening reagents, and ketamine.

\subsection{Research Procedure}

\section{a. Making Turmeric Simplicia (Curcuma Longa)}

The identified turmeric (Curcuma Longa) was washed with running water, then drained and spread on parchment paper until the water was absorbed, after which the turmeric (Curcuma Longa) sample was weighed. Then the material is air-dried. The weight of the dry material was weighed. Dry ingredients from turmeric (Curcuma Longa) are ground into powder and form simplicia(Kosasih et al., 2019).

\section{b. Making Turmeric (Curcuma Longa) Ethanol Extract}

Turmeric simplicia (Curcuma Longa) was then weighed as much as 200 grams each, then weighedextraction using maceration technique with $96 \%$ ethanol solvent. Let stand for 5 days, the container must be protected from direct light or light while stirring frequently, shred, squeeze, wash the dregs with enough liquid to obtain $4 \mathrm{~L}$. Then the simplicia is transferred to a closed vessel, leave in a cool place, protected from light for 2 day. Then this simplicia is filtered. The results obtained were concentrated by using a Rotary Evaporator until most of the solvent evaporated which was then continued by the evaporation process on a water bath until a thick extract was obtained (ethanol extract).Turmeric / Curcuma Longa) (Depkes RI, 1979).

\section{c. Phytochemical Screening}

In the phytochemical test study using a modified Fansworth method consisting of identification of phenols, steroids/triterpenoids, terpenoids, saponins, flavonoids, tannins and alkaloids. (Widowati et al., 2016, 2017, 2018).

1. Phenol Identification

Testing is carried out on the plate in drops, the sample is added with $\mathrm{FeCl} 3$ (1\% in water/ethanol), if there is a green/red/purple/blue/black color change, it indicates the presence of phenol content.

2. Identification of Steroids/Triterpenoids

The sample was stored on a drip plate, then added with anhydrous acetic acid until submerged, left for 10-15 minutes, then added 1 drop of concentrated sulfuric acid (H2SO4). If there is a green/blue color change indicates the presence of steroids, the presence of a red/orange precipitate indicates the presence of triterpenoids.

3. Identification of Saponins

The sample was dissolved in aquadest and shaken vigorously, then observed what happened, the saponin content was indicated by the formation of a stable foam above the solution.

4. Identification of Tannins

The sample is immersed in taThe reaction tube with $2 \mathrm{~N} \mathrm{HCl}$ solution was then heated on a water bath for 30 minutes and a positive reaction was indicated by the 
formation of orange/red in the amyl alcohol layer (top layer).

5. Terpenoid Identification

The sample is placed on the plate the next drop is added vanillin and H2SO4 solution, a positive reaction is indicated by a color change that occurs to a purple color.

6. Identification of Flavonoids

The sample is put in the tubereaction containing $\mathrm{Mg} / \mathrm{Zn}$ granules and then added $2 \mathrm{~N} \mathrm{HCl}$ solution, then incubated for 5-10 minutes and added amyl alcohol solution to the filtrate. A positive reaction is indicated by the formation of a red-orange color.

7. Identification of Alkaloids

The sample was added with $10 \%$ ammonia solution, then extracted with chloroform and formed 2 layers, the bottom layer was transferred to a new test tube and $2 \mathrm{~N}$ $\mathrm{HCl}$ was added then the acid layer (top layer) was transferred back to a new test tube and added Dragendrof solution. A positive reaction is indicated by the formation of a yellow to brick red precipitate.

\section{d. Anti-Dyslipidemic Effect Test}

a. Preparation of $0.5 \% \mathrm{Na}$ CMC Suspension

As much as 0.5 grams of $\mathrm{Na}$ CMC was sprinkled into a mortar containing $10 \mathrm{~mL}$ of hot distilled water. Let stand for 15 minutes until a transparent mass is obtained, crushed to form a gel and diluted with a little distilled water, then poured into a 100 $\mathrm{mL}$ volumetric flask, plus distilled water to the mark. This suspension will be used further in the next stage as a dispersing medium in making oral suspensions (colloids).(Mutia and Chiuman, 2019)

b. PTU suspension manufacture

A total of $100 \mathrm{mg}$ of PTU was ground in a mortar to a powder, then $0.5 \% \mathrm{Na}$ CMC suspension was added and then put into a $10 \mathrm{ml}$ volumetric flask. The volume is made up with $0.5 \% \mathrm{Na}$ CMC suspension to the limit line(Untari and Pramukatoro, 2020).

c. Turmeric Extract Suspension (Curcnuma Longa).

A total of 1.2 grams of turmeric extract (Curcnuma Longa) was put into a mortar and added $0.5 \% \mathrm{Na}$ CMC suspension little by little while grinding until homogeneous and then put into a $10 \mathrm{~mL}$ volumetric flask. The volume was made up with $0.5 \% \mathrm{Na}$ CMC suspension to the mark line.(Mutia and Chiuman, 2019).

d. Simvastatin Suspension Manufacturing

A total of $10 \mathrm{mg}$ of simvastatin was ground in a mortar to a powder, then $0.5 \% \mathrm{Na}$ CMC suspension was added and then put into a $25 \mathrm{~mL}$ volumetric flask. The volume was made up with $0.5 \% \mathrm{Na}$ CMC suspension to the mark line(Fouad and Jresat, 2013; Aldahmash and El-Nagar, 2016).

e. Induction of Dyslipidemia in Experimental Animals

The induction process was carried out by giving Propylthiouracil (PTU) to experimental animals for 14 days. Propylthiouracil (PTU) is given as an oral suspension at a dose of $12.5 \mathrm{mg}$ /day $(1.25 \mathrm{ml} /$ day) in 2 divided doses. (Subhawa Harsa, 2014; Untari and Pramukantoro, 2020)

f. Testing on Test Animals

A week before the intervention was carried out on all experimental animals, the experimental animals were first acclimatized to a laboratory environment. After that, all wistar rats were induced using Propylthiouracil (PTU), except from the 
normal group. After 14 days, the test animals with total cholesterol $240 \mathrm{mg} / \mathrm{dl}$ were declared to have dyslipidemia. However, before measuring total cholesterol levels, all rats were fasted for at least 8 hours. The test animals were divided into 6 groups and each consisted of 4 experimental animals. Doses of turmeric ethanol extract and simvastatin as a standard group, were determined based on previous studies(Olayinka et al., 2014; Batubara, Sabri and Tanjung, 2017; Worotikan, Tuju and Kawuwung, 2017; Abarikwu et al., 2020). The treatment experienced by each rat in the group was as follows:

Table 2. Description of the Treatment of Each Group

\begin{tabular}{|c|c|c|}
\hline No & Test Group & Treatment \\
\hline 1. & Normal & $\begin{array}{l}\text { Test animals were not given any particular treatment and } \\
\text { were only given food and drink on an ad libitium basis. }\end{array}$ \\
\hline 2. & Control & $\begin{array}{l}\text { Test animals were given } 1 \mathrm{ml} \text { of } 0.5 \% \mathrm{Na} \text { CMC suspension } \\
\text { once a day for } 14 \text { days. Food and drinks are provided ad } \\
\text { libitum. }\end{array}$ \\
\hline 3. & $\begin{array}{l}\text { Standard } \\
(25 \mathrm{mg} / \mathrm{kgBW})\end{array}$ & $\begin{array}{l}\text { Test animals were given simvastatin oral suspension } 5 \mathrm{ml} / \mathrm{kg} \\
\text { once a day for } 14 \text { days. Food and drinks are provided ad } \\
\text { libitum. }\end{array}$ \\
\hline 4. & $\begin{array}{l}\text { Turmeric Extract (Curcuma } \\
\text { Longa) - I ( } 300 \mathrm{mg} / \mathrm{kgBW})\end{array}$ & $\begin{array}{l}\text { Test animals were given Turmeric Extract (Curcuma Longa) } \\
\text { at a dose of } 2.5 \mathrm{ml} / \mathrm{kgBW} \text { once a day for } 14 \text { days. Food and } \\
\text { drinks are provided ad libitum. }\end{array}$ \\
\hline 5. & $\begin{array}{l}\text { Turmeric Extract (Curcuma } \\
\text { Longa) - II } \\
(600 \mathrm{mg} / \mathrm{kgBW})\end{array}$ & $\begin{array}{l}\text { Test animals were given Turmeric Extract (Curcuma Longa) } \\
\text { at a dose of } 5 \mathrm{ml} / \mathrm{kgBW} \text { once a day for } 14 \text { days. Food and } \\
\text { drinks are provided ad libitum. }\end{array}$ \\
\hline 6. & $\begin{array}{l}\text { Turmeric Extract (Curcuma } \\
\text { Longa) - III } \\
(1200 \mathrm{mg} / \mathrm{kgBW})\end{array}$ & $\begin{array}{l}\text { Test animals were given Turmeric Extract (Curcuma Longa) } \\
\text { at a dose of } 10 \mathrm{ml} / \mathrm{kgBW} \text { once a day for } 14 \text { days. Food and } \\
\text { drinks are provided ad libitum. }\end{array}$ \\
\hline
\end{tabular}

\section{e. Measurement of Lipid Profile Parameters}

Before taking blood, rats were fasted for at least 8 hours before taking blood. Blood was drawn by direct withdrawal from the rat heart as much as $1 \mathrm{ml}$. It was put into a microtube and allowed to stand for \pm 20 minutes. Then the blood was centrifuged at 3000 rpm for 15 minutes to obtain rat blood serum. Lipid profiling was determined by the colorimetric method. Lipid profile examination was carried out at the Health Laboratory, North Sumatra Provincial Health Office.

\section{g. Measurement of SGOT and SGPT Biochemical Parameters}

Blood was drawn by direct withdrawal from the rat heart as much as $1 \mathrm{ml}$. It was put into a microtube and allowed to stand for \pm 20 minutes. Then the blood was centrifuged at $3000 \mathrm{rpm}$ for 15 minutes to obtain rat blood serum. The determination of SGOT and SGPT levels is based on enzymatic reactions using the Dyasis ${ }^{\circledR}$ reagent kit. The procedure for determining the activity of SGOT and SGPT catalysts is based on the working procedure of Dyasis®. SGOT and SGPT examinations were carried out at the Health Laboratory, North Sumatra Provincial Health Office.

\subsection{Data Analysis}

The research data were then analyzed using the SPSS 25 program. The research data were analyzed descriptively (Central tendency and Dyspersion) from the research data in the form of lipid profiles (LDL, HDL, Total Cholesterol, and Triglycerides), color, texture, 
weight. Then the research data in the form of lipid profiles were analyzed by One-Way Anova if the data were normally distributed with a follow-up test in the form of the Post Hoc Tukey HSD test to see significant differences between treatments. However, as an alternative test if the data is not normally distributed, the Kruskall-Wallis test is used as an alternative test.

\section{Discussion}

\subsection{Results}

\section{a. Extract Characteristics}

After Extraction was carried out by maceration method on samples of ethanolic turmeric (Curcuma Longa) and the characteristics of the extract were as follows.

Table 3. Turmeric (Curcuma Longa) Ethanol Extract Characteristics

\begin{tabular}{ll}
\hline \multicolumn{1}{c}{ Characteristics } & Mark \\
\hline Fresh Simplicia Weight (gr) & $500 \mathrm{gr}$ \\
Dry Simplicia Powder Weight (gr) & $214 \mathrm{gr}$ \\
Solvent Volume (ml) & $2120 \mathrm{ml}$ \\
Extract Weight (gr) & $15.22 \mathrm{gr}$ \\
Yield (\%) & $7.22 \%$ \\
\hline
\end{tabular}

From data from the table above, it can be seen that from 500 grams of turmeric (Curcuma Longa), 15.22 grams of extract were found. Thus, the yield obtained from the ethanol extract of turmeric (Curcuma Longa) was 7.22\%.

\section{b. Phytochemical Screening}

Results Phytochemical screening on samples of turmeric ethanol extract (Curcuma Longa) can be seen in the following table.

Table 4. Results of Phytochemical Screening of Turmeric Ethanol Extract (Curcuma

\begin{tabular}{llc}
\multicolumn{1}{c}{ Longa) } & Results \\
\hline Phytochemicals & Reactor & + \\
& Bouchardart & + \\
& Mayer & - \\
& Dragondrop & + \\
Saponins & Wagner & - \\
Flavonoids & FeCl3 5\% 5 & + \\
& $\mathrm{Mg}(\mathrm{s})+\mathrm{HCl}(\mathrm{p})$ & - \\
& $\mathrm{NaOH} 10 \%$ & - \\
Tannins & $\mathrm{H} 2 \mathrm{SO} 4(\mathrm{p})$ & - \\
Steroids and Terpenoids & FeCl3 1\% & + \\
& Salkowsky & - \\
\hline
\end{tabular}

From data from the table above, it can be seen that the ethanol extract of turmeric (Curcuma Longa) contains several phytochemical compounds including Alkaloids, Saponins, Flavonoids, Tannins, and Steroids and Terpenoids.

\section{c. Evaluation of Anti-Dyslipidemic Effect}

All parameters evaluated in this study including body weight, total cholesterol, lipid profile, levels of SGOT, and SGPT were analyzed for normality of the data using the 
Shapiro-Wilk test. The results of the normality analysis can be seen in the table below.

Table 5. Results of Data Normality Test with Shapiro-Wilk Test on All Research Parameters

\begin{tabular}{lllc}
\hline Parameter & P value & Data Distribution \\
\hline Weight & 0.399 & Normal \\
\hline Total Cholesterol Before Induction & $<0.05$ & Abnormal \\
\hline Total Cholesterol After Induction & $<0.05$ & Abnormal \\
\hline \multirow{2}{*}{$\begin{array}{l}\text { Lipid Profile } \\
\text { After Treatment }\end{array}$} & Total Cholesterol & 0.445 & Normal \\
\cline { 2 - 4 } & Triglycerides & 0.004 & Abnormal \\
\cline { 2 - 4 } & HDL levels & $<0.05$ & Abnormal \\
\cline { 2 - 4 } & LDL levels & 0.143 & Normal \\
\hline SGOT level & & $<0.05$ & Abnormal \\
\hline SGPT level & & 0.056 & Normal \\
\hline
\end{tabular}

From the table data above, it can be seen that the data on body weight, total cholesterol and LDL levels from the lipid profile after treatment, and SGPT levels had normal data distributions, while other parameters included: total cholesterol before and after induction, triglyceride levels, HDL levels, and SGOT levels were not normally distributed. Based on the data distribution, data with normal data distribution were analyzed using parametric statistics, while non-normal data were analyzed using nonparametric statistics.

\section{d. Weight}

To uniform the weight of the mice used in this study, all the mice used in this study were weighed first. Then a comparison was made on the whole body weight of the rats. The results of this comparison can be seen in the following table.

Table 6. Comparison of Initial Body Weight of Rats in All Treatment Groups

\begin{tabular}{lccc}
\hline Treatment Group & \multicolumn{2}{c}{ Weight (grams) } & \multirow{2}{*}{ P value } \\
\cline { 2 - 3 } & mean & SD & \\
\hline Normal & 235.00 & 37.75 & \\
Standard & 240.70 & 15.62 & \\
Control & 249.00 & 23.77 & \multirow{2}{*}{0.968} \\
Turmeric (Curcuma Longa) Ethanol Extract I & 247.00 & 25.50 & \\
Turmeric (Curcuma Longa) Ethanol Extract -II & 234.50 & 24.52 & \\
Turmeric (Curcuma Longa) Ethanol Extract -III & 240.55 & 13.87 & \\
\hline
\end{tabular}

From data the table above can be seen that the $\mathrm{P}$ value $>0.05(\mathrm{P}$ value $=0.968)$ which means that there is no significant difference in the initial body weight of the mice used in this study. The weight range of rats used in this study ranged from 210-300grams which were evenly distributed in each treatment group.

\section{e. Total Cholesterol}

In evaluating the anti-dyslipidemic effect of turmeric ethanol (Curcuma Longa), a high-fat diet was administered to the control group, standard, turmeric ethanol extract (Curcuma Longa)-I, II, and III. Before and after administration of PTU, total cholesterol in all mice was measured and all data on total cholesterol were analyzed by non-parametric statistics. The results of the analysis can be seen in the following table. 
Table 7. Comparison of Total Cholesterol Before and After Administration of PTU (Propylthiouracil) in All Treatment Groups

\begin{tabular}{lcc}
\hline \multirow{2}{*}{ Treatment Group } & \multicolumn{2}{c}{ Total Cholesterol (mg/dL) } \\
\cline { 2 - 3 } & Before Induction & After Induction \\
\hline Normal & $117.00(110-115)$ & $118.50(111-123) \mathrm{b}$ \\
Standard & $11,300(110-117)$ & $211.00(209-211) \mathrm{a}$ \\
Control & $116.50(110-115)$ & $210.00(210-214) \mathrm{b}$ \\
Turmeric (Curcuma Longa) Ethanol Extract -I & $116.00(110-115)$ & $210.50(208-212) \mathrm{b}$ \\
Turmeric (Curcuma Longa)-II . Ethanol Extract & $112.50(100-110)$ & $210.00(209-214) \mathrm{b}$ \\
Turmeric (Curcuma Longa) Ethanol Extract-III & $117.00(117-125)$ & $209.50(208-214) \mathrm{b}$ \\
\hline P value & $\mathbf{0 . 8 8 2}$ & $\mathbf{0 . 0 2 7}$ \\
\hline
\end{tabular}

Data is displayed as Median (Range). The P value was obtained from the Kruskal-Wallis analysis; Different superscripts in the same column show significant differences

From data the table above can be seen that before being given a high-fat diet, the total cholesterol of rats before being given a high-fat diet in all treatment groups did not show a significant difference $(\mathrm{P}$ value $=0.882)$. This shows that the total cholesterol data of rats before being given a high-fat diet is uniform. However, the total cholesterol in all groups of rats after being given a high-fat diet showed a different distribution, where only the control group, standard, Turmeric extract (Curcuma Longa)-I, II, and III showed uniform total cholesterol.

\section{f. Lipid Profile}

On At the end of the study, all mice were terminated for blood collection and analysis of lipid profile and liver function (SGOT/SGPT). Comparison of lipid profiles in all rat treatment groups can be seen in the table below.

Table 8. Comparison of Lipid Profiles in All Treatment Groups of Rats

\begin{tabular}{|c|c|c|c|c|}
\hline \multirow[b]{2}{*}{ Treatment Group } & \multicolumn{4}{|c|}{ Lipid Profile } \\
\hline & $\begin{array}{c}\text { Total } \\
\text { Cholesterol* }\end{array}$ & Triglycerides** & LDL* & HDL ** \\
\hline Normal & $133.00 \pm 2.40 \mathrm{a}$ & $97.50(97-100) \mathrm{a}$ & $53.50 \pm 1.64 a$ & $61.50(61-64) \mathrm{a}$ \\
\hline Standard & $147.50 \pm 0.58 b$ & $103.00(101-105) \mathrm{b}$ & $63.00 \pm 1.27 \mathrm{~b}$ & $60.50(60-63) \mathrm{a}$ \\
\hline Control & $178.50 \pm 6.05 c$ & $167.00(162-179) \mathrm{c}$ & $107.20 \pm 3.60 \mathrm{c}$ & $28.50(37-45) b$ \\
\hline Turmeric Ethanol Extract I & $168.25 \pm 1.50 \mathrm{~d}$ & $133.50(133-135) \mathrm{d}$ & $83.75 \pm 2.62 \mathrm{~d}$ & $57.50(56-59) \mathrm{b}$ \\
\hline Turmeric Ethanol Extract II & $163.25 \pm 2.22 \mathrm{e}$ & $120.50(119-122) \mathrm{e}$ & $77.50 \pm 1.29 \mathrm{e}$ & $61.50(61-63) \mathrm{a}$ \\
\hline Turmeric Ethanol Extract III & $151.70 \pm 0.95 \mathrm{e}$ & $110.00(109-112) \mathrm{f}$ & $68.50 \pm 1.28 \mathrm{f}$ & $61.00(60-62) \mathrm{a}$ \\
\hline P value & $<0.05$ & 0.027 & $<0.05$ & 0.027 \\
\hline
\end{tabular}

From data the table above can be seen that all lipid profile data in all treatment groups showed significant differences.

a. Total cholesterol in all rat treatment groups showed a significant difference, this can be seen from the $\mathrm{P}$ value $<0.05$. The lowest average total cholesterol was found in the normal group, namely $133.00 \pm 2.40 \mathrm{mg} / \mathrm{dL}$, followed by the standard group at 147.50 $\pm 0.58 \mathrm{mg} / \mathrm{dL}$, the Turmeric (Curcuma Longa) ethanol extract group I, II, III, and the group with total cholesterol. the highest was the control group at $178.50 \pm 6.02 \mathrm{mg} / \mathrm{dL}$;

b. Triglyceride levels in all treatment groups also showed significant differences, this can be seen from the $\mathrm{P}$ value $<0.05(\mathrm{P}$ value $=0.027)$. The tendency for the lowest triglyceride levels was found in the normal group, namely $97.50 \mathrm{mg} / \mathrm{dL}$, followed by 
the standard group at $103.00 \mathrm{mg} / \mathrm{dL}$, the Turmeric (Curcuma Longa) ethanol extract group I, II, III, and the group with the highest triglyceride levels was the control group of $167.00 \mathrm{mg} / \mathrm{dL}$.

c. LDL levels also showed significant differences in all treatment groups, this can be seen from the $\mathrm{P}$ value $<0.05$. The lowest average LDL level was found in the normal group, namely $53.50 \pm 1.64 \mathrm{mg} / \mathrm{dL}$, followed by the standard group at $63.00 \pm 1.27 \mathrm{mg} / \mathrm{dL}$, the Turmeric (Curcuma Longa) ethanol extract group I, II, III, and the group with LDL levels. the highest was the control group at $107.50 \pm 3.60 \mathrm{mg} / \mathrm{dL}$.

d. HDL levels also showed significant differences in all treatment groups, this can be seen from the $\mathrm{P}$ value $<0.05(\mathrm{P}$ value $=0.027)$. The tendency for the highest HDL levels was found in the normal group, namely $61.50 \mathrm{mg} / \mathrm{dL}$, followed by the standard group at $60.50 \mathrm{mg} / \mathrm{dL}$, the Turmeric extract group (Curcuma Longa) I, II, III, and the group with the lowest HDL levels was the control group at $28.50 . \mathrm{mg} / \mathrm{dL}$.

\section{g. Liver Function}

Other parameters are also assessed in all groups of rats at the end of the study was liver function, namely: SGOT and SGPT levels. Comparison of SGOT and SGPT levels in all rat treatment groups can be seen in the table below.

Table 9. Comparison of SGOT and SGPT Levels in All Treatment Groups

\begin{tabular}{lll}
\hline Treatment Group & SGOT Level (U/L) & SGPT level (U/L) \\
\hline Normal & $27.50(26-30) \mathrm{a}$ & $47.50 \pm 1.50 \mathrm{a}$ \\
Standard & $110.00(106-110) \mathrm{b}$ & $171.00 \pm 1.28 \mathrm{~b}$ \\
Control & $167.50(162-170) \mathrm{c}$ & $97.25 \pm 1.50 \mathrm{c}$ \\
Turmeric (Curcuma Longa) Ethanol Extract -I & $117.50(116-120) \mathrm{d}$ & $100.75 \pm 3.56 \mathrm{~d}$ \\
Turmeric (Curcuma Longa)-II . Ethanol Extract & $121.00(120-124) \mathrm{e}$ & $115.00 \pm 4.50 \mathrm{e}$ \\
Turmeric (Curcuma Longa) Ethanol Extract-III & $129.50(128-130) \mathrm{f}$ & $142.00 \pm 2.08 \mathrm{~b}$ \\
\hline P value & $\mathbf{0 . 0 2 7}$ & $<\mathbf{0 . 0 5}$ \\
\hline
\end{tabular}

*Data is displayed as Mean \pm SD. The $\mathrm{P}$ value was obtained from One Way ANOVA analysis; **Data is displayed as Median (Range). The P value was obtained from the Kruskal-Wallis analysis; Different superscripts in the same column show significant differences

From data the table above shows that the levels of SGOT and SGPT in all rat treatment groups showed significant differences, this can be seen from the $\mathrm{P}$ value $<0.05$. The tendency for the highest SGOT levels was found in the control group, namely 167.50 $\mathrm{U} / \mathrm{L}$ and the lowest in the normal group, namely $27.50 \mathrm{U} / \mathrm{L}$. Meanwhile, a similar picture was found in SGPT levels, the group with the highest SGPT levels was found in the standard group, namely $170.50 \mathrm{U} / \mathrm{L}$ and the lowest was found in the normal group, namely $47.50 \mathrm{U} / \mathrm{L}$.

\subsection{Discussion}

The results of this study showed that the ethanol extract of turmeric (Curcuma Longa) showed a significant improvement in lipid profile at the end of the study. Turmeric ethanol (Curcuma Longa) at the highest dose showed the most optimal improvement in lipid profile. This can be seen from the decrease in total cholesterol, triglyceride, and LDL levels as well as the increase in HDL levels from the Turmeric (Curcuma Longa)-II and III ethanol group. However, this improvement in lipid profile in the Turmeric (Curcuma Longa)-III ethanol group of mice did not exceed the improvement shown in the standard group. The anti-dyslipidemic effect of Turmeric (Curcuma Longa) ethanol extract may be related to the content of various phytochemicals in turmeric rhizome. 
Several studies have demonstrated the potential of these phytochemicals as antidyslipidemia. The content of polyphenols can cause down-regulation of modulation of proinflammatory cell signals such as nuclear factor- $\kappa \mathrm{B}$, activated protein-1, and mitogenactivated protein kinase through inhibition of the arachidonic acid cascade and eicosanoids derivatives. Another possible mechanism for the anti-dyslipidemic effect of polyphenolic compounds is the regulation of gut microbiota. These polyphenolic compounds in the intestine will interact with the gut microbiota thereby increasing various beneficial metabolite products such as short chain free fatty acids, as well as intestinal microbiota such as Akkermansia municiphilia sp. restore inflammatory conditions in the intestine, improve intestinal permeability, and insulin sensitivity. Furthermore,(Sun, Wang and Qin, 2018; Feldman et al., 2021).

Other studies that discuss the anti-dyslipidemic effect of turmeric ethanol are still limited, but the results of Ardhani's research (2017), entitled The Effectiveness of Turmeric Extract (Curcuma domestica) as Non-Pharmacological Therapy for Dyslipidemia and Antiatherosclerosis, states that giving turmeric extract can be a therapy nonpharmacological dyslipidemia and as an antiatherosclerosis agent. Turmeric extract contains the compound curcumin which is an antioxidant. Curcumin can reduce LDL oxidation which plays a role in foam cell formation, suppresses inflammatory processes in blood vessels, and protects blood vessel endothelium from free radicals (Ardhani et al., 2017). Apart from being an antioxidant, curcumin can reduce cholesterol levels due to inhibiting the reabsorption of cholesterol from outside (exogenous) and increasing the enzyme Hmg-CoA reductase inhibitor so that fat synthesis can run well.(Komang and Laksmi, 2014). Treatment and prevention of disease with curcumin is one of the therapeutic modalities that is not inferior to the pharmacological approach (Shishodia et al., 2005).

In addition, turmeric ethanol extract, also significantly reduced levels of SGOT and SGPT compared to the control group. This decrease in SGOT and SGPT levels is associated with improvement in Non-Alcoholic Fatty Liver Disease (NAFLD). Several studies have shown that NAFLD is a risk factor for the development of atherosclerosis. This is because NAFLD causes dysfunction of the vascular endothelium. Thong and Quynh (2021) reported that both SGOT and SGPT correlated with the occurrence of NAFLD, but the use of SGOT and SGPT separately could show errors in confirming mild NAFLD. In severe cases of NAFLD, SGOT will increase slightly and in mild cases SGOT levels can be found in normal amounts. Therefore,(Thong and Quynh, 2021). In this study, the levels of SGOT and SGPT in the group of rats receiving ethanol extract of turmeric (Curcuma Longa) were lower than the levels of SGOT and SGPT in the control group. This shows that turmeric ethanol extract (Curcuma Longa)- can protect liver tissue from NAFLD compared to the group that did not receive turmeric ethanol (Curcuma Longa)-. However, the possibility of mild NAFLD in the group of rats receiving turmeric ethanol (Curcuma Longa) could not be ruled out.

\section{Conclusion}

As for the conclusion that can be drawn from the results of this study is that the ethanol extract of turmeric (Curcuma Longa) III $(151.70 \pm 0.95 \mathrm{mg} / \mathrm{dl})$ can significantly reduce total cholesterol compared to the control group $(178.50 \pm 6.05 \mathrm{mg} / \mathrm{dl})$. ( $\mathrm{P}$ value <

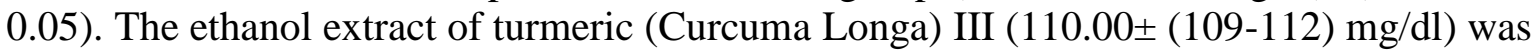
able to significantly reduce triglyceride levels compared to the control group (167.00 (162$179) \mathrm{mg} / \mathrm{dl})$. (P value $=0.027)$. The ethanol extract of turmeric (Curcuma Longa) III (68.50 
$\pm 1.28 \mathrm{mg} / \mathrm{dl})$ could significantly reduce LDL levels compared to the control group (107.20 $\pm 3.60 \mathrm{mg} / \mathrm{dl})$. (P value < 0.05). The ethanol extract of turmeric (Curcuma Longa) III, $(61.00(60-62) \mathrm{mg} / \mathrm{dl})$ could significantly increase HDL levels compared to the control group (28.50 (37-45) mg/dl). (P value $=0.027)$.

\section{References}

Abarikwu, S. O. et al. (2020) 'Evaluation of the protective effects of quercetin and gallic acid against oxidative toxicity in rat's kidney and HEK-293 cells', Toxicology Reports, 7(February), pp. 955-962. doi: 10.1016/j.toxrep.2020.07.015.

Aldahmash, B. A. and El-Nagar, D. M. (2016) 'Antioxidant Effects of Captopril against Lead Acetate-Induced Hepatic and Splenic Tissue Toxicity in Swiss Albino Mice', Saudi Journal of Biological Sciences, 23(6), pp. 667-673. doi: 10.1016/j.sjbs.2016.05.005.

Aparicio, H. J. et al. (2021) Heart Disease and Stroke Statistics-2021 Update A Report from the American Heart Association, Circulation. doi: 10.1161/CIR.0000000000000950.

Ardhani, S. et al. (2017) 'Efektivitas Ekstrak Kunyit (Curcuma domestica) Sebagai Terapi Non Farmakologi Dislipidemia dan Antiaterosklerosis', Medula, 7(5), pp. 194-198.

Bahri, S., Pasaribu, F. and Sitorus, P. (2012) 'Uji Ekstrak Etanol Kulit Buah Manggis (Garcinia Mangostana ,L) Terhadap Penurunan Kadar Glukosa Darah', Journal of Pharmaceutics and Pharmacology, 1(1), pp. 1-8.

Batubara, M. S., Sabri, E. and Tanjung, M. (2017) 'Pengaruh Pemberian Ekstrak Etanol Daun Andaliman (Zanthoxylum acanthopodium DC.) terhadap Gambaran Morfologi Ovarium Mencit (Mus musculus L.) Strain DDW', Klorofil, 1(1), pp. 5-10.

D'Agostino, R. B. et al. (2008) 'General cardiovascular risk profile for use in primary care: The Framingham heart study', Circulation, 117(6), pp. 743-753. doi: 10.1161/CIRCULATIONAHA.107.699579.

Dipiro J et al. (2015) Pharmacoterapy A Phatophysiologic Approach, AIAA Guidance, Navigation, and Control Conference.

El-Sayed, E. M. et al. (2011) 'Cardioprotective effects of Curcuma longa L. extracts against doxorubicin-induced cardiotoxicity in rats', Journal of Medicinal Plants Research, 5(17), pp. 4049-4058.

Feldman, F. et al. (2021) 'Efficacy of polyphenols in the management of dyslipidemia: A focus on clinical studies', Nutrients, 13(2), pp. 1-42. doi: 10.3390/nu13020672.

Fouad, A. A. and Jresat, I. (2013) 'Captopril and telmisartan treatments attenuate cadmium-induced testicular toxicity in rats', Fundamental and Clinical Pharmacology, 27(2), pp. 152-160. doi: 10.1111/j.1472-8206.2011.00974.x.

Gustomi Rima, M. P. L. (2015) 'Ekstrak Rimpang Kunyit Menurunkan Kadar Lemak Darah Pasien Hiperlipidemia (Turmeric (Curcuma Longa Linn) Extract Toward Modification of Blood Lipid Level in Hyperlipidemia Patients)', Journals of Ners Community, 6(Vol 6, No 1 (2015)), pp. 1-7. Available at: http://journal.unigres.ac.id/index.php/JNC/article/view/66.

Irmadoly, N. et al. (2014) 'Uji Aktivitas Antidislipidemia In Vivo Fraksi Ekstrak Daun Salam ( Eugenia polyantha ) pada Tikus Galur Wistar yang diinduksi Diet Tinggi Lemak', Jurnal Kedokteran dan Kesehatan, 1(1), pp. 21-24.

Jijith, U. S. and Jayakumari, S. (2018) 'Screening methods for antihyperlipidemic activity: A review', 10(2), pp. 2017-2019.

Kemenkes RI (2018) 'Hasil Riset Kesehatan Dasar Tahun 2018', Kementrian Kesehatan 
RI, 53(9), pp. 1689-1699.

Komang, N. and Laksmi, S. (2014) 'Continuing Continuing Development Professional Medical Development', 41(11), pp. 823-827.

Kosasih, E. et al. (2019) 'Hepatoprotective Effect of Citrus Sinensis Peel Extract Against Isoniazid and Rifampicin-induced Liver Injury in Wistar Rats', Majalah Obat Tradisional, 24(3), pp. 197-203. doi: 10.22146/mot.45762.

Manarin, G. et al. (2019) 'Curcuma longa L. ameliorates asthma control in children and adolescents: A randomized, double-blind, controlled trial', Journal of Ethnopharmacology, 238, p. 111882. doi: 10.1016/j.jep.2019.111882.

Mutia, M. S. and Chiuman, L. (2019) 'Hepatoprotective Effect of Citrus sinensis ( L .) Osbeck Ethanol Extract in Paracetamol-Induced Rats Efek Hepatoprotektif Ekstrak Etanol Citrus sinensis L . Osbeck pada Tikus yang Diinduksi Parasetamol', Majalah Kedokteran Bandung, 51(4), pp. 189-193.

Olayinka, E. T. et al. (2014) 'Protective effect of quercetin on melphalan-induced oxidative stress and impaired renal and hepatic functions in rat', Chemotherapy Research and Practice, 2014. doi: 10.1155/2014/936526.

Rezzani, R., Franco, C. and Rodella, L. F. (2019) 'Curcumin as a therapeutic strategy in liver diseases', Nutrients, 11(10), pp. 1-7. doi: 10.3390/nu11102498.

Sabale, P., Modi, A. and Sabale, V. (2013) 'Curcuma longa Linn. A Phytochemical and Phytopharmacological Review', Research Journal of Pharmacognosy and Phytochemistry, 5(2), pp. 59-68.

Shishodia, S. et al. (2005) 'Curcumin (diferuloylmethane) inhibits constitutive NF- $\mathrm{B}$ activation, induces G1/S arrest, suppresses proliferation, and induces apoptosis in mantle cell lymphoma', Biochemical Pharmacology, 70(5), pp. 700-713. doi: 10.1016/j.bcp.2005.04.043.

Subhawa Harsa, I. M. (2014) 'Efek Pemberian Diet Tinggi Lemak Terhadap Profil Lemak Darah Tikus Putih (Rattus norvegicus)', Universitas Wijaya Kusuma, 31, pp. 21-28.

Sun, Y. E., Wang, W. and Qin, J. (2018) 'Anti-hyperlipidemia of garlic by reducing the level of total cholesterol and low-density lipoprotein', Medicine (United States), 97(18), pp. 1-8. doi: 10.1097/MD.0000000000010255.

Taufik, F. (2020) 'Skripsi 2020'.

Thong, V. D. and Quynh, B. T. H. (2021) 'Correlation of serum transaminase levels with liver fibrosis assessed by transient elastography in vietnamese patients with nonalcoholic fatty liver disease', International Journal of General Medicine, 14, pp. 1349-1355. doi: 10.2147/IJGM.S309311.

Untari, M. K. and Pramukantoro, G. E. (2020) 'Aktivitas Antihiperkolesterolemia Ekstrak Etanol Daun Stevia Rebaudiana Bertoni Pada Tikus Putih Jantan', Journal Syifa Sciences and Clinical Research, 2(1), pp. 11-20. doi: 10.37311/jsscr.v2i1.2700.

Widowati, W. et al. (2016) 'Antioxidant and Anti Aging Assays of Oryza sativa Extracts, Vanillin and Coumaric Acid', Journal of Natural Remedies, 16(3), pp. 88-99. doi: $10.18311 / \mathrm{jnr} / 2016 / 7220$.

Widowati, W. et al. (2017) 'Antioxidant and antiaging assays of Hibiscus sabdariffa extract and its compounds', Natural Product Sciences, 23(3), pp. 192-200. doi: 10.20307/nps.2017.23.3.192.

Widowati, W. et al. (2018) 'Antioxidant and antiaging activities of Jasminum sambac extract, and its compounds', Journal of Reports in Pharmaceutical Sciences, 7(3), pp. 270-285.

Worotikan, R. V., Tuju, E. A. and Kawuwung, F. (2017) 'Analisa Efektivitas Antidiabetes Ekstrak Etanol Buah Andaliman (Zanthoxylum acanthopodium DC) pada 
Histopatologi Ginjal Tikus Puth (Rattus norvergicus) yang Diinduksi Alloksan', Jurnal Sains Matematika \& Edukasi, 5(1), pp. 29--37.

Wulansari, F. (2020) 'Aktivitas Water Kefir sebagai Antidislipidemia pada Tikus Putih Jantan yang Diinduksi Propylthiouracil (Ptu) dan Emulsi Lemak', Universitas Bhakti Kencana Fakultas Farmasi Program Strata I Farmasi Bandung 2020, Laporan Tu, pp. $5-24$.

Yunarto, N. et al. (2019) 'Aktivitas Antioksidan serta Penghambatan HMG CoA dan Lipase Kombinasi Ekstrak Daun Binahong-Rimpang Temulawak Antioxidant Activity along with Inhibition of HMG CoA Reductase and Lipase from Anredera cordifolia Leaf - Curcuma xanthorrhiza Rhizome Combinati', 9(2), pp. 89-96. 